\title{
FUNCTIONAL AND SPATIAL TRANSFORMATIONS AND CONTEMPORARY ROLE OF EDUCATIONAL GARDEN ON THE EXAMPLE OF SCHOOL GARDEN IN SOBIESZYN
}

\author{
Krystyna Pudelska, Kamila Rojek \\ Department of Ornamental Plants and Landscape Architecture, University of Life Sciences in Lublin \\ Głęboka 28, 20-612 Lublin, Poland, \\ e-mail: krystyna.pudelska@up.lublin.pl
}

\begin{abstract}
An important task for present and future generations is the protection of the national cultural resources. The most attractive architectural objects of historic value include palaces, manors, castles and monasteries. Less attention is paid to educational areas, which apart from the main educational and didactic goal (positive influence on the young person's mind, shaping his personality, social integration) have a great influence on his health, the quality of his life and the shape of his environment. The example of this is the park next to the school complex in Sobieszyn, located in Lublin Voivodeship, Ułęż County. The school complex with its surrounding park established at the end of the $19^{\text {th }}$ century was given by a will of the Count Kajetan Kanty Kicki, Gozdawa coat of arms, a philantropist and a contemporary owner of Sobieszyn. Localisation of the school, far away from the centre of the village, on the slope of one of the right side tributaries of the Wieprz River - Świnka, makes it an extraordinary place, emphasising the nature values that surround it. Nowadays, the building is still a school- Kajetan Kicki Agriculture School in Sobieszyn.
\end{abstract}

Key words: historic school garden, analysis of spatial composition, dendroflora, Sobieszyn

\section{INTRODUCTION}

Sobieszyn is a small village located in the Wieprz River valley in the west part of Lublin Voivodeship. Its history goes back to the $13^{\text {th }}$ century and it is directly connected with the Sobieski family, Janina coat of arms. However, in the $19^{\text {th }}$ and the beginning of the $20^{\text {th }}$ centuries, the Kicki family, Gozdawa coat of arms, had a great influence on the development of the village. In the first half of the $19^{\text {th }}$ century the Kicki family took over Sobieszyn from the Tarnowski family. The Kicki clan with their strong patriotic traditions contributed a lot to the Polish history.The members of the family held some important positions in the country, army and church and they supported social reforms [Kseniak 1983a, Atras 2009].

The Count Kajetan Jan Kanty Konstanty Kicki (1803-1878) became the owner of Sobieszyn estate in 1858 . His higher education and philantropic activity helped to propagate the agricultural knowledge and culture among the farmers [Kseniak 1983a]. It is in Sobieszyn where he was a founder not only of the parish church of The Holy Cross Elevation, but also one of the first agriculture schools in Polish Kingdom where students got their education [Grzechnik 2006]. Nowadays, the school still offers agricultural and horticultural profiles. As the Count Kajetan Kicki stated in his testament, the main goal of the school was to ,increase well - being, morality and education among the local people" [Białecki 1882]. The Count strongly supported the need of the agricultural education of young people and the introduction of modern farming methods which would increase the level of agriculture and life in the country [Atras 2009].

Following the guidelines of the Education Committee, in the Age of Reason, natural sciences were introduced to the school curriculum in Poland. Next to some schools, e.g in Szczuczyn Litewski (1785), there appeared small educational gardens [Grębecka 1993] as work in the garden and on the field is to teach plant cultivation and most of all it should develop positive values about nature in young people. "What we teach children at school, they will know and do as adults" [Jankowski 1918]. Many publications of those days emphasised an important role 
of a school garden in the children and the teenage education [Karczewska 1906, Sikora 1910, Jankowski 1918, 1929]. „The best way to exercise your body and play and learn at the same time is to do gardening in the open and in the fresh air [......] practical and theoretical agriculture courses for the secondary school students let them aquire the great knowledge of natural sciences, influencing their intelectual education" [Sikora 1910]. This form of education was practised not only in Europe, but also on the American continent. At the beginning of the $20^{\text {th }}$ century in the USA a new educational programme, which aim was to improve students' knowledge about horticulture, earth science and the environmnent was introduced. In the school garden in Cleveland, the students cultivated plants, which were later on introduced in home and district gardens. The green was used as the educational material for cognitive aims and as nursary plants [Mader 2010]. That role of the school gardens was propagated by Władysław Szafer. In his publication 'School gardens' (1921) Szafer described three types of gardens: public school gardens, secondary school gardens and university gardens with the species expositions in all the places. The gardens were also used for the educational and the research purposes and for the practical activities of children and teenagers. In the $50 \mathrm{~s}$ of the $20^{\text {th }}$ century the Ministry of Education in 'The instruction about a school garden as an experimental place' claimed the need to organise a research school garden next to all kinds of school ${ }^{1}$.

Is there any area next to the schools nowadays that one can call a school garden which the Count Kicki meant in his testament?

The turn of the $20^{\text {th }}$ and the $21^{\text {st }}$ centuries marked the introduction of the changes in the forms and the function of the greenery surrounding schools. Its number and a role in education decreased [Kowalski 1992]. There appeared „green classrooms”, places for „green lessons”, recreational places or places for doing experiments and organising expositions. These places were created by the students and for the students. They became the places that young people could identify with as they were the areas of their ,common work and common effort” [Kossobucka 2007].

In 2005 the United Nations published a guide for teachers, parents and the local communities with some guidelines how to set up and organise a school garden to protect the society against the famine and how to teach children healthy eating habits [Sherman 2005]. In the era of increasing number of the overweight children and the diseases resulting from this problem, e.g diabetes or heart diseases, a school garden regains its function- as an educational place, a place for lessons and physical exercises [Ozer 2007, Ratcliffe et al. 2009].

The example of the preserved $19^{\text {th }}$ century park in Sobieszyn, a former school garden next to the Agriculture School, made it possible to follow the changes in the spatial system, the structure of the area and the dendroflora of this object, which is 119 years old. The study shows an important role of the $19^{\text {th }}$ century Agriculture and Horticulure School to the young people.

\section{LOCALISATION OF THE SCHOOL}

The Count Kajetan Kicki Agriculture School is localised in the northwestern part of Sobieszyn, $800 \mathrm{~m}$ from the road 48 (Dęblin - Kock). The area of the school covering 12 ha together with the entrance alley has been listed in the historical treasure registry of Lublin Voivodeship under the number A/807 since 1980. A maple-lime alley of the length of $750 \mathrm{~m}$ leads to the school. To the north the school complex borders with a huge complex of ponds, which belongs to the Protected Landscape Area of the Wieprz River, to the north-west it borders with a forest and to the west with the research fields of the school. To the east it borders with the residential areas.

1 Official Journal of the Ministry of Education No. 8, item. 62, "Manual of 13 May 1954. On the plot experimental school" 


\section{THE HISTORY OF THE SCHOOL}

The Count Kajetan Kicki is remembered in the Polish history as a well-educated man, entrepreneur, a man of a generous heart and a famous philantropist. In the year of his death in 1878 he made a testament in which he asked his inheritor to build the Agriculture School and the church as in Sobieszyn the Kicki family has resided since the beginning of the $19^{\text {th }}$ century. The testator made 'The Association of Agricultural Settlements and Guilds of Craftsmen' the inheritor and contractor of his testament [Atras 2009]. In 1892 a place for building a school was chosen. Following the guidelines of the village council, the school was localised not far away from the village centre, on the hill called 'Birch Mountain'. The red brick school was placed on the highest point of the plot, given a shape of E letter [Jakubiak 1996] (Fig. 1.).

At the same time there were built storage rooms (a cowshed, a warehouse, a basement and a barn) [Krzyżanowska 1995]. The designer of the school building was Apoloniusz Nieniewski. The opening ceremony of the school took place on 3 March 1896 and 16 students began the school year. In 1900 a functional-utility programme was enriched with new buildings and so called 'Headmaster's House' and some houses for the teachers. The same year, the $19^{\text {th }}$ century Larch Mansion called 'The white' was moved from the Kicki's estate from Blizocina. It was located on the west side of the school complex. It served as a hunters' inn for the school guests [Kseniak 1983b, Wiącek 2001]. Nowadays one can find an exhibition room there. The park covering the area of 12, 25 ha and a maple- larch alley were created together with the school. The first headmaster of the school- Stanisław Domosławski, a scientist and a lifelong worker of the research station in Sobieszyn is said to be the creator of the park and the school garden in the school complex [Wiącek 2001].Unfortunately, a plan of the gardens from those days is not left. The entrance alley leading to the school (the length of $750 \mathrm{~m}$ ) was grown with the tree species of Acer platanoides and Tilia cordata and to commemorate the headmaster it was called Stanisław Domosławski Alley [Wiącek 2001]. The period of Stanisław Domosławski as a headmaster of the school (1896-1914) was the time of its best development [Lipski i Łuczyński 2009]. Then, the area of the school complex was 150 ha. Crops (spring and winter), bulb plants and vegetables were grown. The experiments with different species of crops and chemical fertilizers were conducted. The school became famous for the land cultivation of rare species of vegetables. A vast area was covered by the plantation of asparagus which was sent to Petersburg. Seeds and seedlings of other species were sold to the local inhabitants. Next to the school, there was an orchard, trees and fruit bushes (fruit and tree seedlings were given out to people) and there was also animals livestock farming [Grzechnik 2006].

On the basis of the Count Kajetan Kicki's testament, in Sobieszyn there was built the parish church of The Holy Cross Elevation on the hill called 'Larch Hill' (1923-1929). As a result of that, the Kicki's mansion, the church and the Agriculture School were organised in a shape of a triangle (Fig. 2.). In the 80 s of the $20^{\text {th }}$ century they were listed in the historical treasure registry. Until the present times, all the buildings have represented a particular cultural value. They constitute a valuable element of the landscape, prove the development of the innovation and the creativity of the Count Kajetan Kicki. He claimed, following the idea of the Age of Reason that the future starts at school, drawing attantion to the school buildings, which according to him, should not destroy the beauty of the landscape: „I claim and draw my attantion to the fact that whatever will be decided about the buildings, would not destroy the beauty of the landscape, but rather complete it"2

2 The quotation comes from a will of Count K. Kicki [source: Grzechnik 2006] 


\section{MATERIAL AND METHODS}

The research of the school garden in the school complex in Sobieszyn consisted of a query of archival materials: historic maps, some uniform texts or texts full of references. In 2009 a detailed inventory of a tree stand in the school park and the entrance alley was conducted. Botanical nomenclature was proposed by Seneta i Dolatowski (2011). The height of the trees was measured by means of an altimeter Suunto PM-5/1520 and a tape measure at the height of $130 \mathrm{~cm}$ above the ground was used for trunk circumference. The possible age of the trees was defined on the basis of the age charts by Longin Majdecki (1980-1986) [Majdecki 1993]. For the analysis of the functional-spatial area, the following maps were used: the tactical map of Poland at scale of 1:10000 from 1937 [http 1], the situational plan of the Agriculture High School in Sobieszyn by S. Pałkowski (1952), a plan of the historic school complex in Sobieszyn made by M. Kseniak (1983b) and a detailed inventory plan of a tree stand prepared by G. Gruza in 2009. Some analysis of the species and age structures of the trees were conducted and some most valuable specimen were differentiated. On the basis of the analysis by $\mathrm{M}$. Ruciński from 1998 some monumental trees for the protection were chosen.

\section{SPATIAL AND FUNCTIONAL CHANGES OF A SCHOOL GARDEN}

Available documents and publications showing the school history allow for the description of the spatial changes of the garden in Sobieszyn. The first preserved plan from 1937 shows that a school garden of a rectangular shape was surrounded from the west and partly from the east by the fields belonging to the school. In the central part, on the highest natural point a school building was well visible. The entrance alley leading from the south to the north constituted the main axis of the complex on which one could find the school garden with the school and two more buildings (a cowshed and a barn) which were at the end of it. The north border of the school garden marked a forest with some ponds behind it. In front of the school, the entrance alley went in the eastern and western directions and then it led to the ponds to the north making three parallel roads.

This communicative system in the garden did not constitute a symmetrical composition, but it was only its reference. One of the alleys (the western one) went through the dense forest and opened the view from the park to the ponds (Fig. 3). In the $30 \mathrm{~s}$ of the $20^{\text {th }}$ century a school garden in Sobieszyn covered the area of 12 ha: 3 ha of the utility garden and nursery, 3 ha of orchards with an apiary together with green areas and sports equipment. Utility gardens, probably for growing vegetables, the nursery of trees and fruit bushes covered the area next to the school entrance. There were four garden quarters of the equal size divided by roads crossing at the right angle. The north border of this garden constituted a wild cherry alley of the length 500 ha, grown in 1922 (Fig. 4). Sports facilities on the school area- a tennis court, a volleyball court or some workout equipment, were probably placed around the school yard. In the 50s of the $20^{\text {th }}$ century the school area was 150 ha and it covered 106 ha of the arable land, 19 ha of meadows, 7 ha of forests, 2 ha of the research field and 13 ha of wasteland [Grzechnik 2006].

On the basis of the plan from 1951 it can be concluded that the system of the main alleys stayed the same and in the central part some new paths were added. In front of the school there was built a circular driveway and from the north a decorative, quartered Italian-style garden (Fig. 5). It covered three tarraces divided into six equal quarters by the roads of the same width. Kseniak (1983a) describes the first two quarters filled with decorative species of blooming trees and surrounded by (Thuja) arborvitae, the next two quarters as an open bosquet and the last two as bosquets filled with small-leaved lime trees, European larch and black locust. The rest of the manor complex was organised in a naturalistic style, which was justified in case of the park established at the turn of the $19^{\text {th }}$ and the $20^{\text {th }}$ centuries. 
Those times gardens were eclectic in style and they harmonised with different styles of buildings. On the plan from 1951 there were clearly marked detailed spatial elements of the school garden, which emphasised its function. There belonged utility gardens in the eastern and western part, orchards and research fields and a sports stadium next to the boarding house in the northwestern part.

On the next plan made in the 80 s of the $20^{\text {th }}$ century by M. Kseniak (1983b) it is shown that a communicative system in the area of the school complex was similar to the one from the $50 \mathrm{~s}$ of the $20^{\text {th }}$ century. Localisation and the function of the school gardens remained the same - a decorative quartered garden, vegetable gardens and a sports stadium. There were also left three alleys constituting the base of a garden composition from 1937. There were also left open views to the ponds complex. New spatial elements which appeared in the north part was a tractor driving course place and a shooting range. The school remained the same - Agriculture and Horticulture School.

\section{ANALYSIS OF THE PARK'S COMPOSITION}

Spatial system of the present park in Sobieszyn has remained in a very good condition and is a part of the composition from 1951 (Fig. 6). It is based on three alleys, surrounded by three smaller decorative and utilitarian parts. Nowadays, a quartered system is still visible , but its species is very much different from the original. The first two quarters, the nearest to the palace are surrounded by different species of Thuja occidentalis, but in their centre there is a lawn. The rest four quarters are covered with aging trees Tilia cordata, Larix decidua and Robinia pseudacacia, but in their centre there are younger species of Acer platanoides and some species of coniferous bushes.

A significant part of the school garden constitutes sports and recreational areas: a playing field, tennis court, shooting range and a barbecue place. A former vegetable garden is replaced by the lawn and a former place for tractor driving course is covered by selfseedings. The area of a former utility garden localised next to the driveway to the school is much smaller now, one part of it is an orchard and the rest is a car park. Single trees prove the existence of a wild cherry trees alley leading to the east.

At the beginning of the 21 st century a school established on the basis of a testament by the Count Kajetan Kicki, apart from teaching students the agriculture and horticulture added a new profile - agrobusiness and a military training.

\section{TREE STAND OF THE PARK}

A valuable tree stand in the park in Sobieszyn constitutes 46 taxa. There grow here 941 deciduous and corniferous trees, 107 bushes and 4 vines. Most species are naitive species. Nowadays, the most numerous and the most different taking into consideration their age are: maple- 205 trees (19,5\% of the present dendroflora), Robinia pseudacacia $-115(10,9 \%)$ and small-leaved limes $-75(7,13 \%)$ as well as spruce ( 52 trees $-4,9 \%$ of the whole tree stand).

The present tree stand is multigenerational. The oldest trees, probably over 120 years old, existing before the school was built, constitute almost $5 \%$ of the whole tree stand. There belong the species which still create a row of red oak at the northern border of the park along the road next to the ponds, hornbeam in the complex and the single species of a small-leaved lime, black poplar and (Thuja) arborvitae (fig. 7). The trees at the age from 120 to 70 constitute $37 \%$ of the whole tree stand. It is most of all a maple -lime alley leading to the school and a single species of a small-leaved lime, maple, white poplar, Thuja, black poplar or a bird cherry that grow at 'Larch Mansion' and at 'Headmaster's House'. The youngest tree stand $(60 \%$ of the tree stand) is mainly selfseeding and coincidental plantings introduced by the subsequent owners. A school garden in Sobieszyn is full of nature monuments. 21 trees received a status 
of the nature monuments: the fluttering elm (Ulmus laevis) petiolate oak, a row of 13 red oaks, sessile oak, spruce, European larch and Thuja occidentalis which are in a good condition. The next 56 trees represented mainly by maple, hornbeam, a small-leaved lime or silver birch can be under nature monument protection.

In the area of the park there are a lot of bushes, which make groups in different parts of the garden. These are Forsythia $x$ intermedia, Thuja occidentalis 'Wareana', Juniperus communis and Philadelphus coronarius. Apart from the trees and bushes there are some vines in the park, i.e. Parthenocisus inserta next to the former house building and Vitis viticella next to the present boarding house.

\section{CONCLUSION}

School gardens popular in the $19^{\text {th }}$ century were the places of educational, teaching and training character. Their main goal was to educate and teach teenagers through work, raise awareness of the young generation and teach patriotism [Sikora 1910, Jankowski 1918]. At the end of the $20^{\text {th }}$ century school gardens were called ,green areas surrounding a school” and they belonged to the group of green areas surrounding some cultural and social institutions, eg. hospitals or stadiums [Czarnecki 1961, Niemirski 1973].

Does the schools' surrounding play educational and teaching role in which some natural science workshops, sports activities or thematic presentations can be organised? The example of the changes in the school garden in Sobieszyn shows that it has been adapted to its goals for over hundred years. The profile of the school still remains agricultural, but the former building adjusted to the realisation of some didactic, practical and educational activities has been reduced.

Nowadays, the school garden with its historic tree stand is used as the recreational area. It is most of all a decorative garden without any former utility gardens, eg. a vegetable garden has been turned into i.e. parking lots. Grassy sports fields, a tennis court and a driving course area on the border of the present park have remained. There are no more gardens of practical character with research areas of orchard,vegetable and decorative species. There has remained the most valuable tree stand in the tree rows of a red oak and a common hornbeam as well as single species of lime tree, black poplar and arborvitae.

For the last several years more and more attention has been paid to the role of a school garden, which has to serve the didactic institution not ,accompany” it. A lot of studies prove useful influence of these areas on mental development, sensitivity, general well-being and creativity of young people [Robinson and Zajicek 2005, Somerset and Markwell 2009, RosłonSzeryńska 2013].

Nowadays, teenagers can identify with this space around a school. A teenager who identifies with a school garden is less agressive and concentrates on work in a school garden [Daszewska 1950]. School gardens also teach cooperation, how to make up decisions, solve problems and cope with stress [Waliczek et al. 1996, 2001, Ozer 2007]. They also help create ecological attitude of teenagers and healthy eating habits among young people [Kelder et al. 1994, Robinson and Zajicek 2005, Morgan et al. 2010].

\section{BIBLIOGRAPHY}

Atras Z., 2009. Wielki patriota, czy jeszcze większy marzyciel?, Nestor - czasopismo artystyczne: 14-17.

Białecki A., 1882. Projekt pierwszych działań do wprowadzenia w życie zapisu hrabiego Kajetana Kickiego, podany Komitetowi Towarzystwa Osad Rolnych i Przytułków Rzemieślniczych. In: Rocznik Towarzystwa Osad Rolnych i Przytułków Rzemieślniczych za rok 1881. Wydany staraniem Zarządu Towarzystwa w Drukarni Józefa Sikorskiego, Warecka Nr. 6, Warszawa.

Czarnecki 1961 . Planowanie miast i osiedli. T.III: Tereny zielone. PWN. Warszawa-Poznań.

Daszewska W., 1950. Hodowle i Ogródek w przedszkolu. Nasza Księgarnia, Warszawa. 
Grębecka W., 1993. Stanisław Bonifacy Jundziłł — wybitny uczony polskiego oświecenia (1761—1847) In: Wkład Pijarów do nauki i kultury w Polsce XVII-XIX w. I. Stasiewicz-Jasiukowa (ed), Warszawa-Kraków: 239-263.

Gruza G., 2010. Revalorization of a park in school complex in Sobieszyn (Lublin province). Master's tesis, University of Life Sciences in Lublin, Poland, $147 \mathrm{p}$.

Grzechnik M., 2006. 1886-2006: 110 lat Szkoły w Sobieszynie-Brzozowej, Stowarzyszenie „Koło Sobieszyniaków”, Sobieszyn.

Jakubiak M., 1996. Sto lat szkoły rolniczej w Sobieszynie [One hundred years of an agricultural school in Sobieszyn]. Sobieszyn.

Jankowski E., 1918. Ogród przy szkole wiejskiej [A garden at a village school]. „Księgarnia Polska” Tow. Polskiej Macierzy Szkolnej. Warszawa.

Jankowski E., 1929. Ogród przy szkole powszechnej [A garden at the comprehensive school] „Księgarnia Polska” Tow. Polskiej Macierzy Szkolnej. Warszawa.

Karczewska M., 1906. Ogród przy ochronce wiejskiej[A garden at a rural nursery habitat] Wydawnictwo Wydziału Ogrodnictwa Kobiecego, p.16.

Kelder S.H., Perry C.L., Klepp K., Lytle L.L. 1994. Longitudinal tracking of adolescent smoking, physical activity, and food choice behaviors. Am. J. of Public Health 84 (7): 1121-1126.

Kossobucka A., 2007. Ogród w przestrzeni szkoły [In:] Dydaktyka biologii wobec wyzwań współczesności, R. M. Suska-Wróbel, I. Majcher (eds). Fundacja Rozwoju Uniwersytetu Gdańskiego, Gdańsk

Kowalski R. 1992. Stan ogrodów szkolnych i problem ich wykorzystania w nauczaniu biologii. Zeszyty Naukowe Wyższej Szkoły Rolniczo-Pedagogicznej w Siedlcach, 33 seria - Nauki Humanistyczne - Pedagogika 4: $117-131$.

Krzyżanowska H. ,et. al.’, 1995. Zabytki Architektury i Budownictwa w Polsce. Województwo lubelskie, Ośrodek Dokumentacji Zabytków, Warszawa.

Kseniak M., 1983a. Parki i ogrody dworskie w województwie lubelskim, Cz. II, PTTK. Lublin

Kseniak M., 1983b. Plan zabytkowego zespołu szkolnego w Sobieszynie. In: Parki i ogrody dworskie w województwie lubelskim, Cz. II, PTTK. Lublin: 110.

Lipski Z., Łuczyński A., 2009. Powiat rycki. Poznaj jego walory. Biuro turystyki Szkolnej, Dęblin.

Majder J., 2010. Cleveland School Gardens. Printed by Arcadia Publishing, Chicago, USA

Majdecki L., 1993. Ochrona i konserwacja zabytkowych założeń ogrodowych, Wyd. PWN, Warszawa.

Morgan P.J., Warren J. M., Lubans D.R., Saunders K.L., Quck G. I., Collins C.E., 2010. The impact of nutrition education with and without a school garden on knowledge, vegetable intake and preferences and quality of school life among primary-school students. Public Health Nutrition 13 (11): 1931-1940.

Niemirski W.,1973. Kształtowanie terenów zieleni. Red. W.Niemirski. Arkady. Warszawa.

Ozer E.J., 2007. The effects of school gardens on students and schools: conceptualization and considerations for maximizing healthy development. Health Educ Behav vol. 34: 846-863.

Pałkowski S., 1952. Zespół szkoły Rolniczej. Plan Sytuacyjny, Prezydium Powiatowej Rady Narodowej w Garwolinie, Warszawa.

Ratcliffe M.M., Merrigan K.A, Rogers B. L., Goldberg J.P., 2009. The effects of school garden experiences on Middle school - aged students' knowledge, attitudes, and behaviors associated with vegetable consumption. Health Promotion Practice. Society for Public Health Education. Available online at http://www.urbansprouts. org/wp-content/uploads/2009/12/Ratcliffe-et-al_The-effects-of-school-garden-experiences_HPP_electronic_2009.pdf, cited on 29 Sept 2015.

Robinson C.W., Zajicek J.M., 2005. Growing Minds: The effects of a one - year school garden program on six constructs of life skills of elementary school children. Hort Technology 15(3):453-457/

Rosłon-Szeryńska E., Gawłowska A., 2013. Rola i funkcja roślin w ogrodzie przedszkolnym na przykładzie wybranych placówek przedszkolnych w Warszawie. In: Episteme, Szczepanik (ed), Kraków nr 18, t.II: 217-229.

Ruciński M., 1998. Motywy i kryteria uznawania tworów przyrody za pomniki. Las Polski, 23:7-10.

Seneta W., Dolatowski J., 2011. Dendrologia. Wydawnictwo PWN. Warszawa.

Sherman j., 2005. Setting up and running a school garden. A manual for teacher, parents and communities. Food and Agriculture Organization of the United Nations. Rome. p.199.

Sikora L. 1910., Wpływ nauki ogrodnictwa na rozwój intelektualny, moralny o fizyczny młodzieży szkół średnich. Gorlice. Nakład Miłośników Ogrodnictwa. Drukiem Zygmunta Turowicza.

Somerset S., Markwell K. 2009. Impact of s school-based food garden on attitudes and identification skills regarding vegatables and fruits: a 12-month intervention trial. Public Health Nutr. 12: 214-221.

Szafer W. 1921. Ogrody szkolne. Książnica Polskiego Towarzystwa Nauczycieli Szkół Wyższych, Lwów - Warszawa, p. 36.

Waliczek T.M., Mattson R.H., Zajicek J.M., 1996. Psychological benefis of community gardening. J. Environ. Hort. 14: 204-209.

Waliczek T.M., Bradley J.C., Zajicek J.M., 2001. The effect of school gardens on children's interpersonal relationships and attitudes toward school. Hort Technology 11(3): 466-468.

Wiącek W., 2001. Szkoła na Brzozowej Górze, Spotkania z zabytkami 1:29-30. 
http//1: Mapa Taktyczna Polski w skali 1:10000 z roku 1937, Tactical map of Poland at scale 1:10000 from 1937. Available online at http://igrek.amzp.pl/4456; cited on 05 Sept 2015.

http//2: Chronicle Sobieszyn. Available online at http://www.fotosik.pl/u/sobieszynkronika/; cited on 01 July 2015.

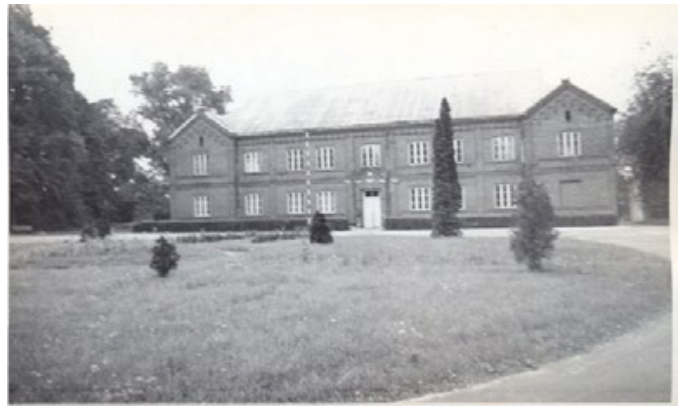

a

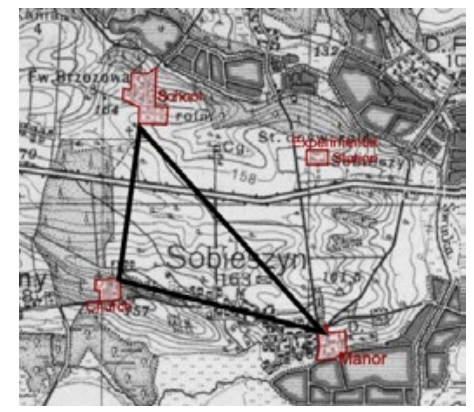

$\mathrm{b}$

Fig. 1. The front elevation of the Agriculture School in Sobieszyn in the $60 \mathrm{~s}$ of the $20^{\text {th }}$ century [source: http 2] Ryc. 1. Elewacja frontowa Szkoły Rolniczej w Sobieszynie, lata 60 XX wieku [źródło: http 2]

Fig. 2. The plan of Sobieszyn and its area [Based on a historic map of 1937 by K. Rojek]

Ryc. 2. Plan Sobieszyna i okolic [Opracowanie K. Rojek na podstawie planu z 1937 roku]

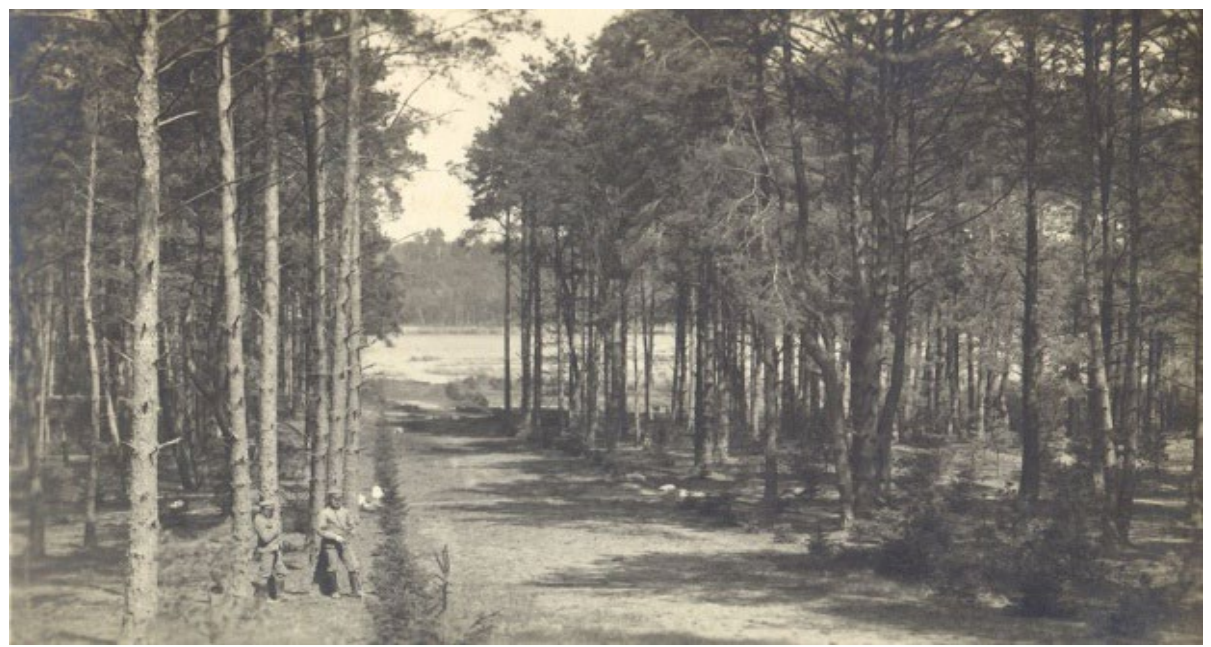

Fig. 3. The ponds view from the park in Sobieszyn to the south, the 20s of the $20^{\text {th }}$ century [source: http 2] Ryc. 3. Widok na staw z wnętrza parku w Sobieszynie w kierunku południowym, lata 20 XX wieku [Źródło: http2] 


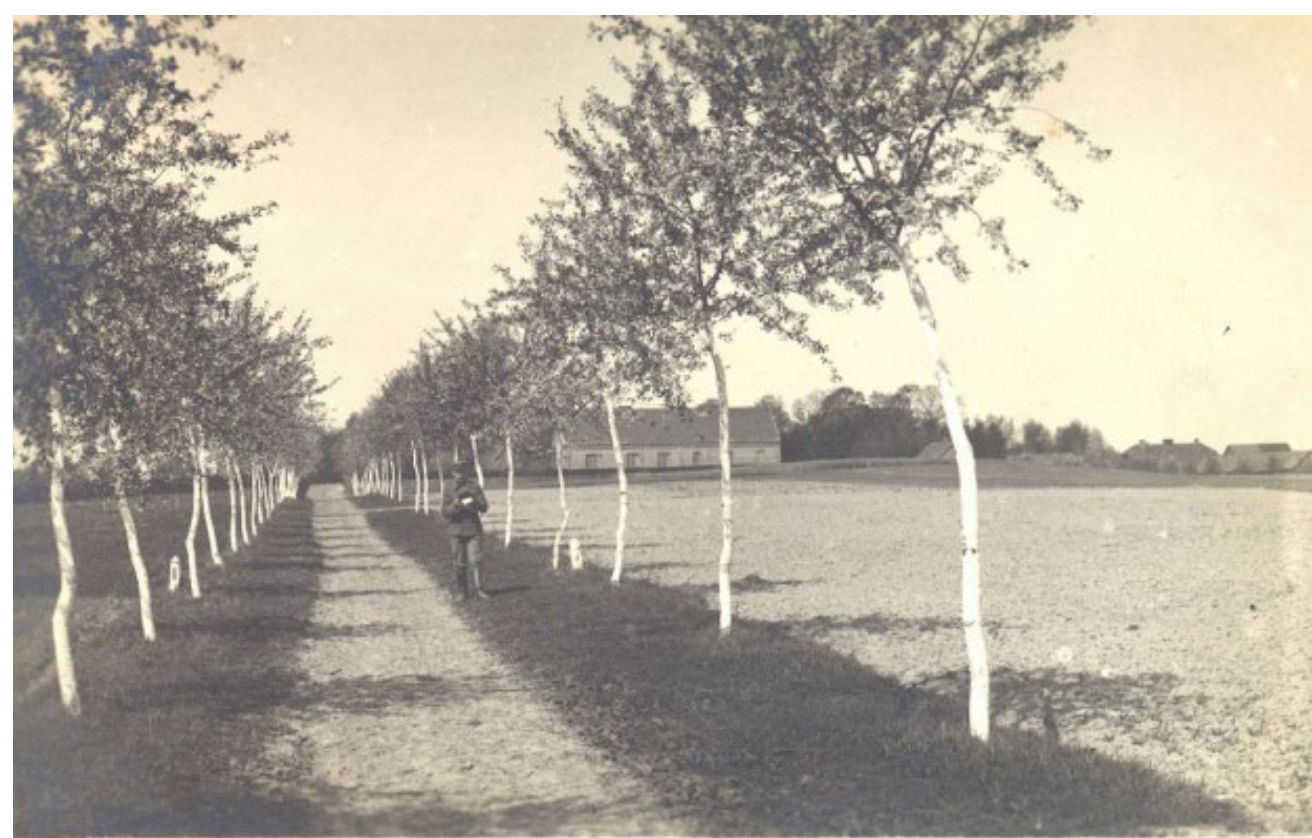

Fig. 4. Wild cherry alley next to the Agriculture School in Sobieszyn, 1922 [source: http 2] Ryc. 4. Aleja wiśniowa przy Szkole Rolniczej w Sobieszynie, 1922 [Źródło: http 2]



Fig. 5. The garden elevation of the Agriculture School in Sobieszyn and a part of the quartered garden, the $60 \mathrm{~s}$ of the $20^{\text {th }}$ century [source: http 2]

Ryc. 5. Elewacja ogrodowa budynku Szkoły Rolniczej w Sobieszynie i widok części ogrodu kwaterowego, lata 60-te XX wieku [Źródło: http 2] 


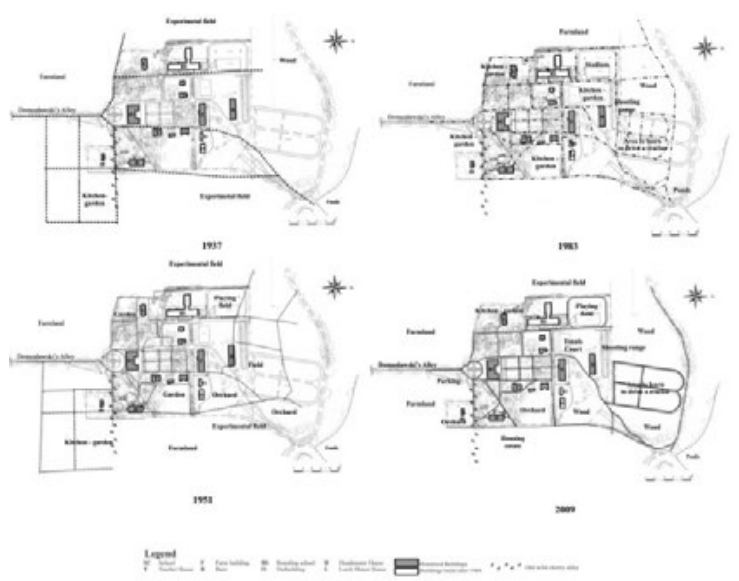

Fig. 6. Schemes changes of school garden in Sobieszyn [Author: K. Rojek] Ryc. 6. Schematy przemian ogrodu przyszkolnego w Sobieszynie [Autor: K. Rojek]

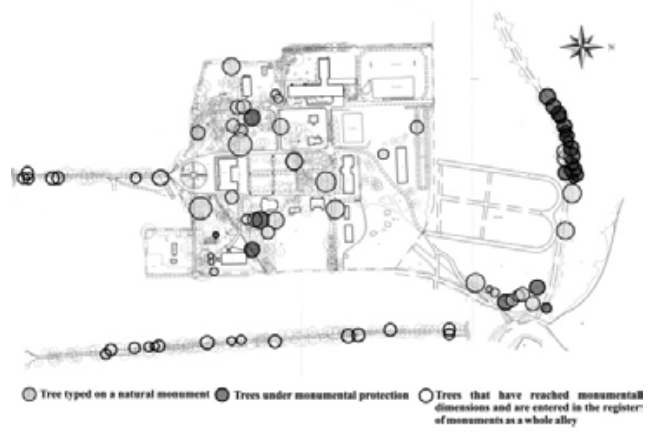

Fig. 7. The oldest trees in the park [Author: K. Rojek] Ryc. 7. Mapa najstarszych drzew w parku [Autor: K. Rojek]

\section{PRZEMIANY FUNKCJONALNO-PRZESTRZENNE \\ I WSPÓŁCZESNA ROLA OGRODU EDUKACYJNEGO NA PRZYKŁADZIE OGRODU SZKOLNEGO W SOBIESZYNIE}

Streszczenie. Ważnym zadaniem dla obecnych i przyszłych pokoleń jest ochrona wszelkich zasobów kultury rodzimej. Wśród najatrakcyjniejszych obiektów architektonicznych o wartości historycznej są rezydencje pałacowe, dworskie, zamkowe, klasztorne. Mniej uwagi poświęca się terenom edukacyjnym, które oprócz głównej funkcji wychowawczo-dydaktycznej - korzystne oddziaływanie na psychikę młodego człowieka, kształtowanie jego osobowości, integrację społeczną - mają dobroczynny wpływ na zdrowie, jakość życia człowieka, kształtują jego otoczenie. Takim przykładem jest park przy zespole szkolnym w Sobieszynie - położony w województwie lubelskim, gminie Ułęż. Zespół szkolny z otaczającym parkiem został założony w końcu XIX wieku na mocy testamentu hrabiego Kajetana Jana Kantego Kickiego, herbu Gozdawa, filantropa i ówczesnego właściciela wsi Sobieszyn. Lokalizacja placówki, z dala od centrum wsi, na zboczu jednego z prawobrzeżnych dopływów rzeki Wieprz - Świnki sprawia, że do chwili obecnej jest miejscem wyjątkowym, podkreślającym walory otaczającego krajobrazu. Obiekt nadal pełni funkcję edukacyjną, jego użytkownikiem jest Zespół Szkół Rolniczych.

Słowa kluczowe: szkolny ogród zabytkowy, analiza kompozycji przestrzennej, dendroflora, Sobieszyn 